\title{
EVALUATION OF ZEBU NELLORE CATTLE BLOOD SAMPLES USING THE CELL-DYN 3500 HEMATOLOGY ANALYZER
}

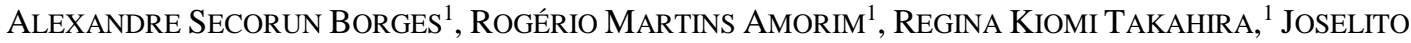 \\ Nunes Costa ${ }^{2}$, Nayro Xavier AlencaR ${ }^{3}$, Ana Paula Cardoso Peixoto, Aguemi \\ KOHAYAGAWA ${ }^{1}$, MARCIO RUBENS GRAF KUCHEMBUCK ${ }^{1}$
}

\author{
${ }^{1}$ Professores Doutores da Faculdade de medicina Veterinária e Zootecnia da UNESP, Botucatu, SP, Brasil. \\ asborges@fmvz.unesp.br \\ ${ }^{2}$ Professor Doutor da Universidade Federal da Bahia, Salvador, BA, Brasil. \\ ${ }^{3}$ Professor Doutor da Universidade Federal Fluminense, Niterói, RJ, Brasil.
}

The Cell-dyn 3500 is a multiparameter flow cytometer, which may analyze samples from several species performing several simultaneous analyses. It is able to perform white blood cells, red blood cells and platelet counts, besides differential leukocyte counts, packed cell volume and hemoglobin determination. Cell-Dyn 3500 performs total leukocyte count both optically and by impedance. The equipment may choose one or other method, based on the reliability of the results. Erythrocyte and platelet counts are determined by impedance. Leukocyte differentiation is based on an optical principle, using separation in multiangular polarized light. The objective of this study was to compare the results of complete blood count of Zebu Nellore heifers from Celldyn 3500, with those obtained from a semi-automated cell counter (Celm CC 510) and the manual technique. Blood samples were collected from the jugular vein in $5 \mathrm{~mL}$ EDTA vacuum tubes from 58 Nellore heifers, at 24 months of age. Samples were processed in parallel in the three different techniques. Results were analyzed using paired t test, Pearson's correlation and the Bland-Altmann method. There was a strong correlation for all parameters analyzed by Cell-Dyn 3500, manual method and semiautomated cell counter, except for basophils and monocytes counts. These results confirm that this analyzer is reliable for blood samples analysis of zebu cattle.

KEYWORDS: CC-510; Cell-Dyn 3500; hematology; Nellore.

\section{AVALIAÇÃO DE AMOSTRAS DE SANGUE DE GADO ZEBUÍNO NELORE USANDO O ANALISADOR HEMATOLÓGICO CELL-DYN 3500}

\section{RESUMO}

O Cell-Dyn 3500 é um citômetro de fluxo multiparâmetros que realiza várias análises simultâneas em diversas espécies de animais. Ele realiza a contagem total de leucócitos, de hemácias e de plaquetas, além do diferencial de leucócitos, o volume globular e a determinação de hemoglobina. O Cell-Dyn 3500 realiza a contagem total de leucócitos, tanto pelo método óptico quanto pela impedância. $\mathrm{O}$ equipamento pode escolher um ou outro método, baseado na confiabilidade dos resultados. A contagem de hemáceas e plaquetas é determinada pelo método de impedância. A diferenciação de leucócitos é baseada em um princípio óptico de análise, utilizando-se separação em luz polarizada multiangular. O objetivo deste trabalho foi comparar os resultados de hemogramas, realizados pelo Cell-Dyn 3500, com aqueles realizados por um contador celular semi-automático (Celm CC-510) e pela técnica manual. Amostras de sangue foram colhidas da veia jugular, em tubos de 5,0 ml à vácuo com EDTA, de 58 novilhas Nelore de 24 meses de idade. As amostras foram processadas paralelamente nas três técnicas. Os resultados foram analisados pelo teste t pareado, correlação de Pearson e pelo método de BlandAltmann. Houve forte correlação entre os resultados hematológicos obtidos pelo Cell-Dyn 3500, pelo método 
manual e pelo contador celular semi-automático (Celm CC-510), exceto para a contagem de basófilos e monócitos. Esses resultados confirmam que o equipamento é confiável para a análise de amostras de sangue de gado zebuíno.

PALAVRAS-CHAVE: CC-150; Cell-Dyn 3500; hematologia; Nelore.

\section{INTRODUCTION}

The analysis of a great amount of blood samples, using conventional methods, implies in excess labor and requires quick transportation to the laboratory. Several laboratories have been using automated equipment in their routine. This device can analyze a large number of samples in short time.

Advances in hematological count automation have produced devices capable of performing leukocyte differential counts, which allows a significant gain in time and precision when compared with manual differential counts ${ }^{1}$.

The Cell-dyn 3500 (Abbott Diagnostic Division, CA, USA) is a multiparameter flow cytometer, which may analyze samples from several species performing several simultaneous analyses. This equipment is mostly used in private veterinary practice, followed by research institutions in the United States ${ }^{2}$. It is able to perform white blood cells (WBC), red blood cells (RBC) and platelet counts, besides differential leukocyte counts, packed cell volume (PCV) and hemoglobin determination.

Cell-Dyn 3500 performs total leukocyte count both optically and by impedance. The equipment may choose one or other method based on the reliability of the results. Erythrocyte and platelet counts are determined by impedance. Leukocyte differentiation is based on an optical principle using separation in multiangular polarized light ${ }^{3}$.

Although Cell-Dyn 3500 is widely used in veterinary practice in some countries, there are few trials comparing its efficiency with conventional methods ${ }^{4-7}$. The objective of this paper was to compare Cell-Dyn 3500 with conventional methods and determine if it is a reliable equipment to perform bovine complete blood count (CBC).

\section{MATERIAL AND METHODS}

The animals were mechanically restrained in a cattle restraint box and five milliliters of venous blood were collected from the jugular vein from 58 Nellore heifers, 24 months of age and with no clinical abnormalities, in vacuum tubes containing EDTA $10 \%$ in aqueous solution as anticoagulant. Blood was mixed thoroughly, stored at five Celsius degree and analyzed within four hours after sampling.

CBC was performed in Abbott Cell-Dyn 3500 (Abbott Diagnostics, Santa Clara, CA), after calibration procedures. Calibration was performed for a better adjustment of the results to the safety margins of the equipment, as indicated in the user's manual. Samples were submitted to manual RBC and WBC counts in a Neubauer chamber, and to a semiautomatic cell counter ${ }^{8}$ (Celm CC-510, São Paulo, $\mathrm{SP})$.

Hemoglobin was determined by Cell-Dyn 3500 and by Celm-CC 510. PCV, determined by Cell-Dyn 3500, was compared with the value obtained by the microhematocrit tube method using a centrifuge at 12,000 rpm for five minutes.

Blood smears were prepared immediately after sample collection and stained, using a quick hematological staining (Hematocor - Biolog) for differential leukocyte counts. Differential counts were performed manually in 400 cells, by three different technicians, and the mean of the three analyses was compared with Cell-Dyn 3500 results. Mean corpuscular volume (MCV) and mean corpuscular hemoglobin concentration (MCHC) were calculated by the standard methods ${ }^{8}$. Fibrinogen was determined by heat precipitation in the microhematocrit tube at $56{ }^{\circ} \mathrm{C}^{9}$.

Values obtained were analyzed by paired $t$ test in order to compare the different methodologies. Pearson's correlation analysis was performed in order to compare the behavior of the variables. Data were also analyzed by the Bland-Altmann method, in which differences between 2 measurements, obtained by different methods, are plotted against their mean ${ }^{10}$.

\section{RESULTS}

All 58 blood samples were analyzed in the Cell-Dyn in approximately 2 hours.

Mean hematological values, the differences and Pearson's correlation coefficients among Cell-Dyn, Celm CC-510 and manual count are shown in Table 1. Although similar results were obtained in RBC counts, a stronger correlation was obtained between CellDyn 3500 and Celm (r=0,86; Figure 1). 
Table1: Mean hematological values, standard deviation (SD), correlation coefficients (Pearson) and mean difference obtained in Cell-Dyn 3500 (CD), Celm-CC 510 and manual examinations of blood from 58 Nellore heifers

\begin{tabular}{|c|c|c|c|c|c|c|c|}
\hline & $\begin{array}{c}\text { CellDyn } \\
(\mathrm{CD})( \pm \mathrm{SD})\end{array}$ & Celm( $( \pm \mathrm{SD})$ & $\begin{array}{c}\text { Manual } \\
\text { Counts }( \pm \mathrm{SD})\end{array}$ & $\begin{array}{l}\text { Correlation } \\
\text { CD x Celm }\end{array}$ & $\begin{array}{l}\text { Correlation } \\
\text { CDxManual }\end{array}$ & $\begin{array}{l}\text { Mean difference* } \\
( \pm \text { SD)CD x Celm }\end{array}$ & $\begin{array}{l}\text { Mean difference* } \\
( \pm \text { SD)CDxManual }\end{array}$ \\
\hline $\mathrm{RBC} \times 10^{12} / \mathrm{L}$ & $9.00 \pm 0.76 \mathrm{a}$ & $9.50 \pm 0.73 b$ & $8.54 \pm 0.95 \mathrm{c}$ & 0.86 & 0.73 & $0.508(0.398)$ & $-0.454(0.650)$ \\
\hline PCV \% & $38.52 \pm 2.80 \mathrm{a}$ & & $39.74 \pm 3.00 \mathrm{~b}$ & & 0.94 & & $1.222(0.983)$ \\
\hline Hemoglobin g/dL & $13.37 \pm 0.93 \mathrm{a}$ & $14.16 \pm 1.03 \mathrm{~b}$ & & 0.95 & & & $0.793(0.317)$ \\
\hline $\mathrm{MCHC} \mathrm{g} / \mathrm{dL}$ & $34.70 \pm 0.66 \mathrm{a}$ & $35.62 \pm 1.01 \mathrm{~b}$ & & 0.55 & & $0.921(0.850)$ & \\
\hline $\mathrm{MCV} g / \mathrm{dL}$ & $42.98 \pm 3.2 \mathrm{a}$ & $41.92 \pm 3.1 b$ & $46.92 \pm 4.30 \mathrm{c}$ & 0.77 & 0.52 & $-1.057(2.136)$ & $3.939(3.820)$ \\
\hline WBC $\times 10^{9} / \mathrm{L}$ & $11.15 \pm 2.24 \mathrm{a}$ & $12.69 \pm 2.34 b$ & $10.70 \pm 2.66 \mathrm{c}$ & 0.79 & 0.83 & $1.533(1.454)$ & $-0.453(1.478)$ \\
\hline Neutrophils x $10^{9} / \mathrm{L}$ & $3.81 \pm 1.58 \mathrm{a}$ & & $3.45 \pm 1.45 b$ & & 0.95 & & $-0.360(0.481)$ \\
\hline Lymphocytes $\times 10^{9} / \mathrm{L}$ & $5.79 \pm 1.52 \mathrm{a}$ & & $6.68 \pm 1.45 b$ & & 0.93 & & $0.897(0.548)$ \\
\hline Eosinophils $\times 10^{9} / \mathrm{L}$ & $0.71 \pm 0.44 \mathrm{a}$ & & $0.62 \pm 0.33 b$ & & 0.80 & & $-0.087(0.271)$ \\
\hline Monocytes $\times 10^{9} / \mathrm{L}$ & $0.77 \pm 0.28 \mathrm{a}$ & & $0.38 \pm 12 b$ & & 0.35 & & $-0.394(0.261)$ \\
\hline Basophils $\times 10^{9} / \mathrm{L}$ & $0.07 \pm 0.03 \mathrm{a}$ & & $0.03 \pm 0.02 b$ & & 0.12 & & $-0.047(0.039)$ \\
\hline
\end{tabular}

Different letters at the same line indicate statistical difference $(\mathrm{p}<0,05 \%)$

*Bland-Altmann method, in which differences between 2 measurements obtained by different methods are plotted against $\mathrm{t}$
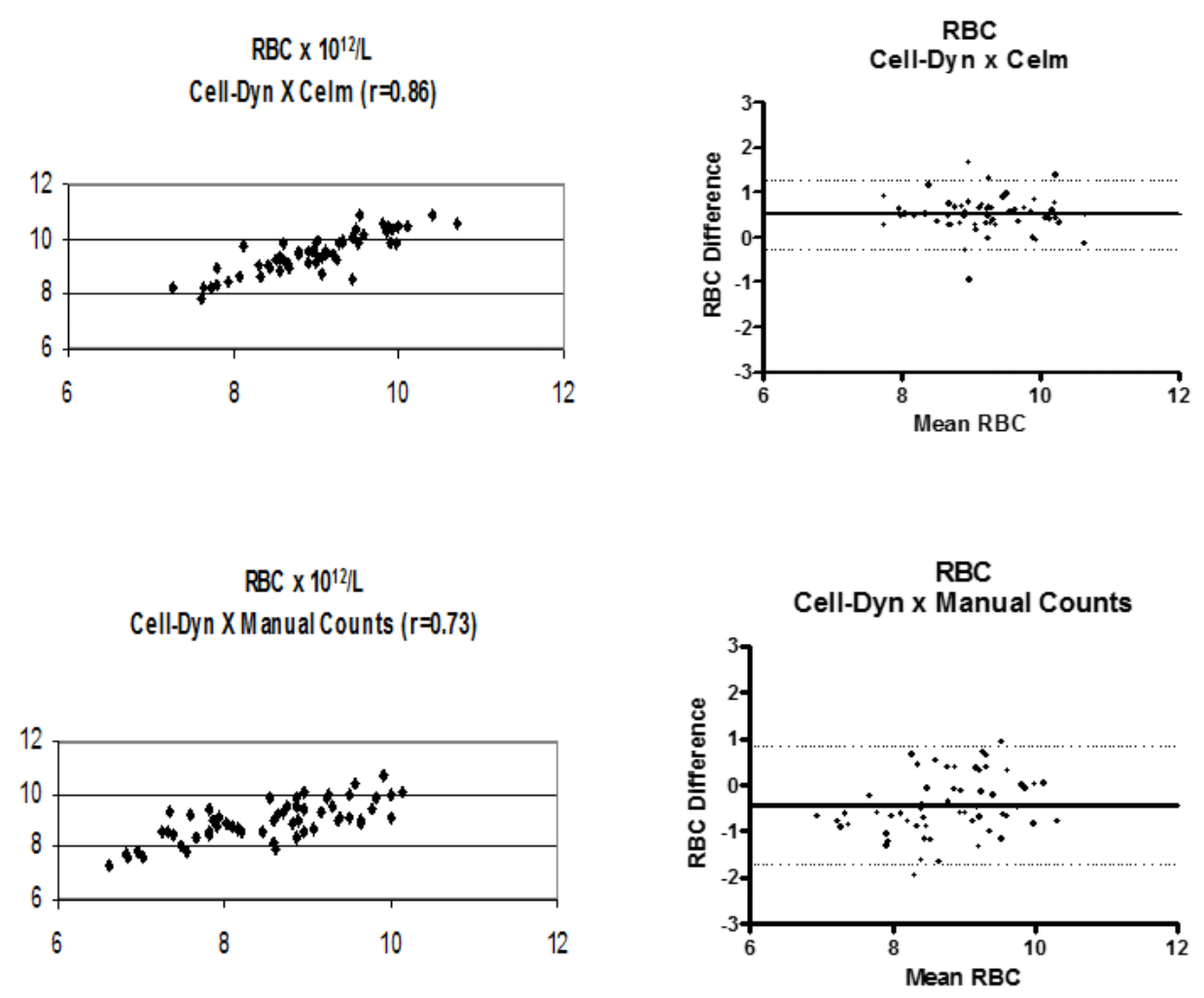

Figure 1: Comparison of red blood count (RBC) values obtained by Cell-Dyn 3500, Celm CC-510 and manual count. Correlation coefficients (left) and mean difference plots (right).

Strong correlations were obtained between the PCV performed in Cell-Dyn 3500 and those in the microhematocrit ( $r=0.94$; Figure 2$)$, as well as between hemoglobin levels determined by Celm and Cell-Dyn 3500 ( $r=0.95$; Figure 3).

Correlation coefficients obtained for the WBC counts were similar for Cell-Dyn 3500 and 
Celm ( $r=0.79$; Figure 4), as well as those obtained in the comparison between Cell-Dyn 3500 and manual counts in the Neubauer chamber $(r=0.83$; Figure 4$)$.

Mean values obtained for RBC and WBC counts were greater in Celm. Intermediate values were obtained in Cell-Dyn 3500 and lower values in the Neubauer chamber (Table 1).

Correlations between the results, for neutrophils and lymphocytes, performed manually in

PCV $(\%)$

Cell-Dyn X Microhematocrit method ( $r=0.94)$

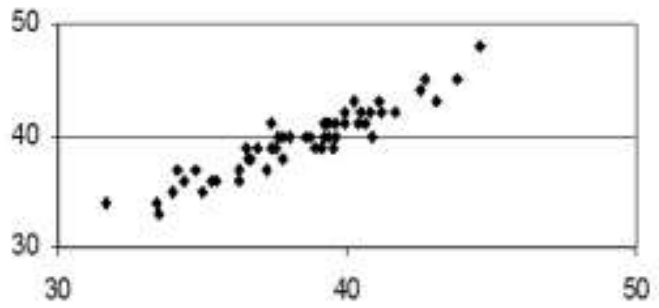

400 cells and those obtained from the reading of 10,000 cells in the Cell-Dyn, were strong ( $r=0.95$ and $\mathrm{r}=0.93$, respectively; Figure 5). Eosinophil counts also presented strong correlation $(\mathrm{r}=0.80$; Figure 6), in the observations of the present study. However, weak correlations were obtained for monocytes and basophils ( $\mathrm{r}=0.35$ and $\mathrm{r}=0.12$, respectively; Figure $7)$.

Figure 2: Comparison of packed cell volume (PCV) values obtained by CellDyn 3500 and microhematocrit method. Correlation coefficients (left) and mean difference plots (right).
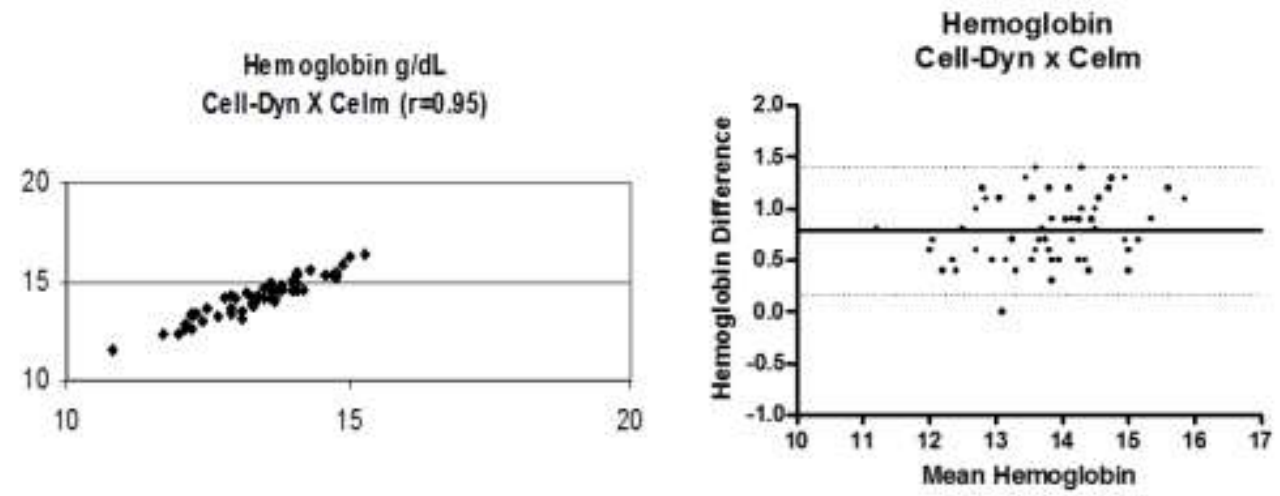

Figure 3: Comparison of hemoglobin values obtained by Cell-Dyn 3500 and Celm. Correlation coefficients (left) and mean difference plots (right). 
WBC $\times 10^{9} \Omega$

Cell-Dyn $\times$ Celm $(r=0.79)$

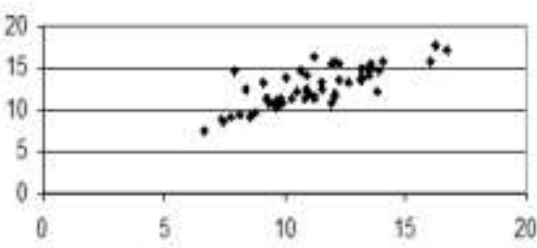

Cell-Dyn X Manual Counts (r=0.83)

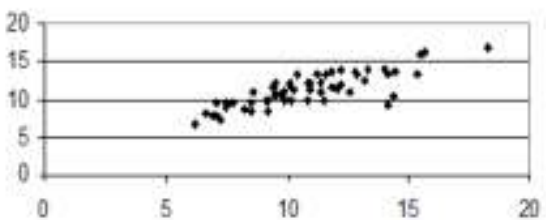

Cell-Dyn $\times$ Ceim

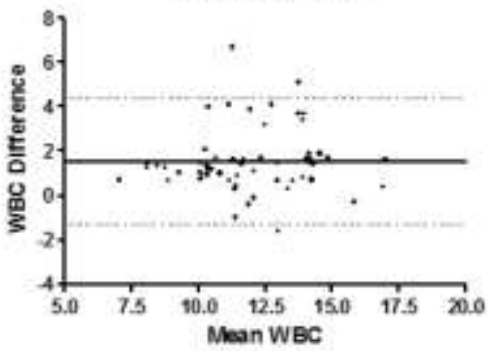

WBC

Cell-Dyn x Manual Counts

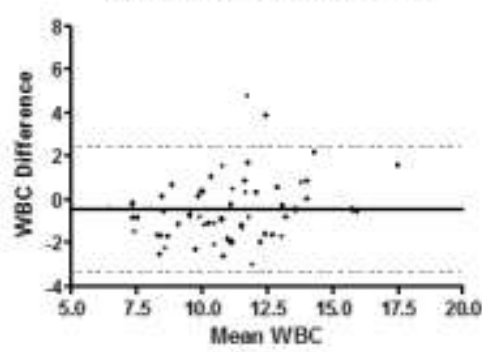

Figure 4: Comparison of white blood cells count obtained by Cell-Dyn 3500 , Celm and manual technique. Correlation coefficients (left) and mean difference plots (right).
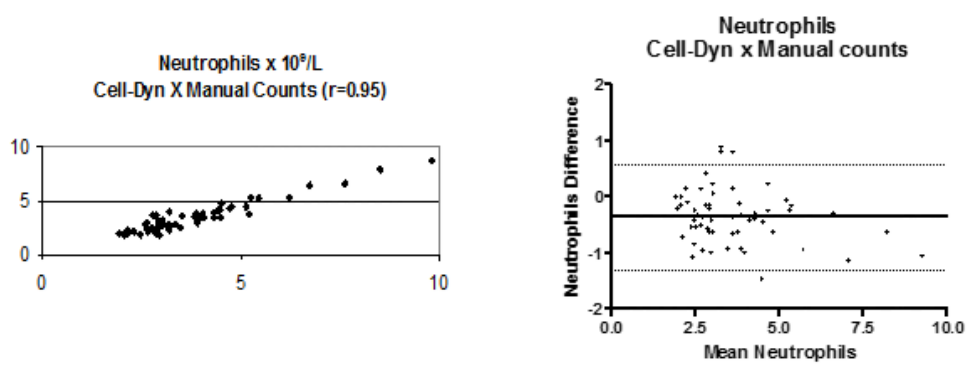

Lymphocytes $\times 10^{9} / \mathrm{L}$ Cell-Dyn X Manual Counts $(r=0.93)$
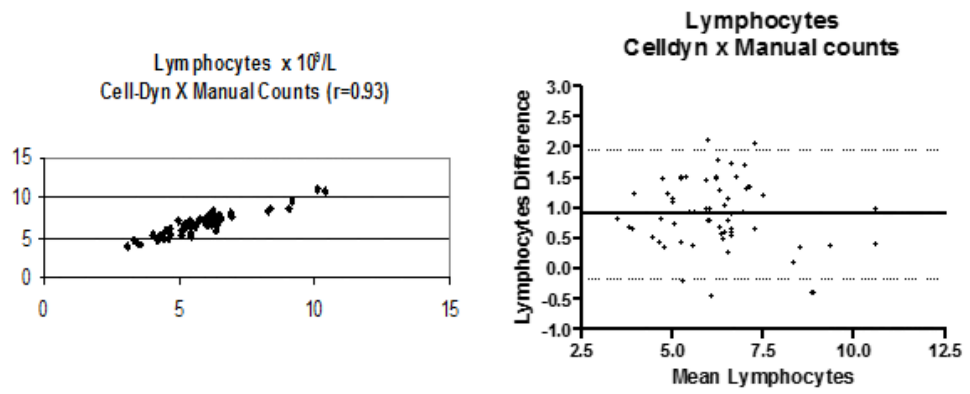

Figure 5: Comparison of neutrophils and lymphocytes values obtained by Cell-Dyn 3500 and manual technique. Correlation coefficients (left) and mean difference plots (right). 

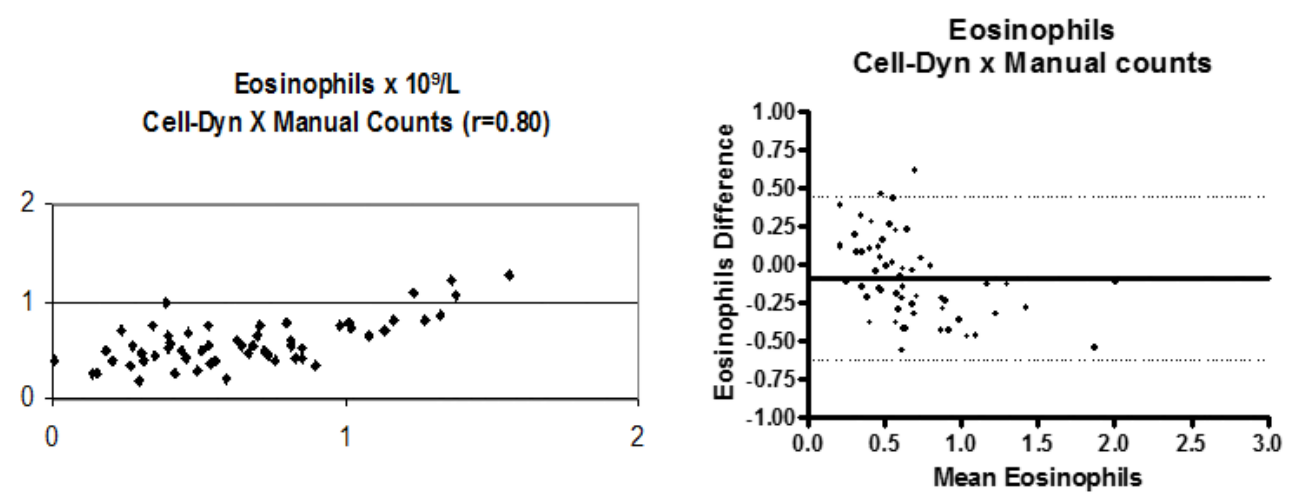

Figure 6: Comparison of eosinophils values obtained by Cell-Dyn 3500 and manual technique. Correlation coefficients (left) and mean difference plots (right).

Monocytes $\times 10^{9} / \mathrm{L}$ Cell-Dyn X Manual Counts $(r=0.35)$

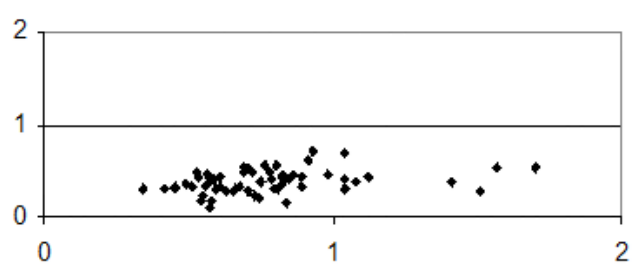

Bas ophils $\times 10^{9} / \mathrm{L}$ Cell-Dyn X Manual Counts $(r=0.12)$

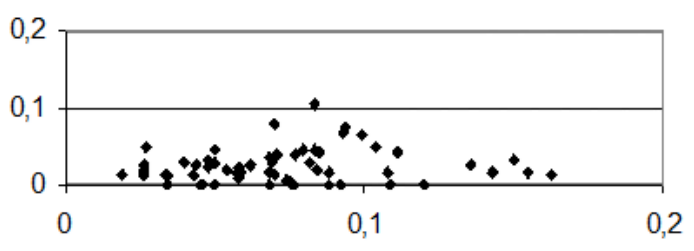

Monocytes

Cell-Dyn x Manual counts

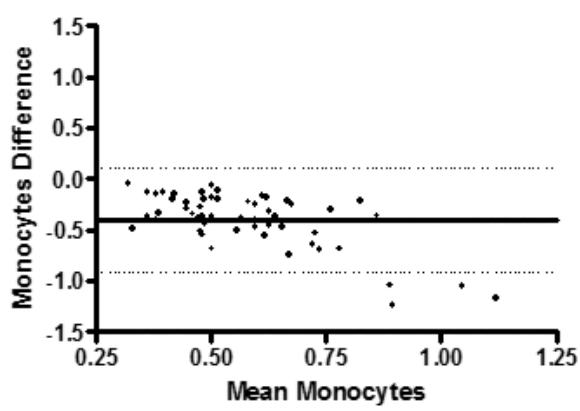

Basophils Cell-Dyn x Manual counts

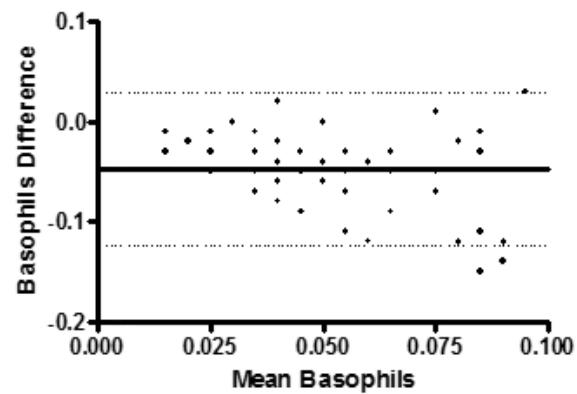

Figure 7: Comparison of monocytes and basophils values obtained by the Cell-Dyn 3500 and manual technique. Correlation coefficients (left) and mean difference plots (right). 


\section{DISCUSSION}

Blood profile is frequently performed in veterinary clinical routine and research and availability of hematology analyzers, for example Cell-Dyn 3500, allows the veterinary clinical pathologist to exam a large numbers of samples in a short time. This advantage was confirmed in our study, because 58 blood profiles were obtained, including differential leukocyte counts, in approximately 2 hours.

However, it is important to remember that most hematological analyzers were manufactured for human beings, and they must be calibrated to be used for different species. Human laboratory evaluation on Cell-Dyn 3500 is well established ${ }^{1,}{ }^{11}$. In veterinary medicine some studies were made to compare hematological parameters among the Cell Dyn 3500, other hematological analyzers and conventional methods ${ }^{4,5,7}$.

Bleul et al. ${ }^{6}$, evaluating the Cell-Dyn 3500 hematology analyzer, collected 399 blood samples from 40 cows and obtained strong correlations for erythrocytes $\quad(\mathrm{r}=0.859)$, leukocytes $\quad(\mathrm{r}=0.960)$, haematocrit $\quad(r=0.968)$, neutrophils $\quad(r=0.973)$, eosinophils $(\mathrm{r}=0.876)$ and lymphocytes $(\mathrm{r}=0.802)$. Moderate correlations were calculated for platelets $(\mathrm{r}=0.706)$ and monocytes $(\mathrm{r}=0.578)$ whereas no meaningful correlation could be established for basophilic granulocytes. Comparing with our study, we found similar results with strong correlation for erythrocytes $\quad(\mathrm{r}=0.73)$, leukocytes $\quad(\mathrm{r}=0.83)$, haematocrit $(\mathrm{r}=0.94)$, neutrophils $\quad(\mathrm{r}=0.95)$, eosinophils $(r=0.80)$ and lymphocytes $(r=0.93)$.

The RBC Pearson's correlation coefficient between Cell Dyn 3500 and Celm CC-510 (table 1) obtained in this study was inferior to those reported by other authors for horses ${ }^{4,5}$. Despite that, the RBC values were within the reference values for Zebu Nellore cattle.

Our results obtained between the PCV performed in Cell-Dyn 3500 and those in the microhematocrit (table 1), as well as between hemoglobin levels determined by Celm and CellDyn 3500 are similar to those reported in the literature for cattle ${ }^{6}$, horses ${ }^{4,5}$ and humans ${ }^{1,} 12$. Similarly, Hennesy et al. ${ }^{4}$ reported an evaluation of the Cell Dyn 3500 in the hematological analyses of blood samples from horses comparing with data obtained from Coulter S880 and manual determinations, and obtained strong correlation ( $p>0,965)$ for hemoglobin concentration, RBC, $\mathrm{MCV}$ and PCV.

Correlations equal to 0.95 , for neutrophils, and 0.93 , for lymphocytes, between the results performed by Cell-Dyn and manual count were, respectively, greater and equal to those obtained in humans ${ }^{1}$. Chow and Leung ${ }^{11}$ found strong correlation, between Cell-Dyn 3500 and differential leukocyte count, for monocytes in human blood samples. However, Bleul et al. ${ }^{6}$ did not find strong correlation for the bovine monocytes, as well as reported in the present trial. Regarding clinical sensitivity, the Cell-Dyn 3500 showed low sensitivity for identification of bovine monocytes, but according to Abbott, we can increase the sensitivity by overall evaluation of the white cell flagging system because it contains a veterinary software program. Weak correlation for basophils, similar to the observed in the present trial, was previously reported for cattle 6 . The same weak correlation for monocytes was observed in studies on humans ${ }^{1,11,12}$

An incomplete separation of lymphocytes and monocytes in the optical channel of the Cell Dyn 3500 analyzer would result in decreased number of lymphocytes and increased number of monocytes ${ }^{6}$. In fact, this pattern was also observed in our study and a possible hypothesis for this is that in blood samples with increased number of monocytes, the examiner may tend to classify questionable monocytes as large lymphocytes during microscopic examination, especially in bovine blood specimens due to the similarity of the two cell types. Buttarello et al. $^{13}$ and Al-Ismail et al. ${ }^{14}$, using electronic methods, also reported the increased number of monocytes compared to values manually determined. Those authors considered the electronic measurements to be accurate and suspected that the manual methods yielded numbers that were falsely decreased. However, it should be emphasized that the values observed were within the reference values for the species?

The weak correlation, obtained for monocytes and basophils did not corroborate the findings that Cell-Dyn 3500 was not able to differentiate bovine leukocytes ${ }^{5,6}$. These inadequate basophil counts are based on the aqueous solubility of the granules in these cells, what makes the counter include them in mononuclear cell counts ${ }^{15}$.

Inaccuracies associated with automated hematology analyzers include possible sedimentation of cells prior to and during the measuring process, the aspiration of air and carry-over of cells from one measurement cycle to the next ${ }^{16}$. However, the CellDyn 3500 software shows an error message to a nonhomogeneous sample or an insufficient volume.

\section{CONCLUSION}

According to the results, we concluded that Cell-Dyn 3500 hematology analyzer is reliable for 
use in zebu cattle, and allows to exam a large number of samples in a short time.

\section{REFERENCES}

1.Vives-Corrons J.L., Besson I., Jou, J.M., Gutierrez G. Evaluation of the Abbott Cell-Dyn 3500 hematology analyzer in university hospital. American Journal of Clinical Pathology. 1996;105:553-559.

2.Gaunt S.D., Prescott-Mathews J.S., King W.W., Scholl D.T. Clinical hematology practices at veterinary teaching hospitals and private diagnostic laboratories. Veterinary Clinical Pathology. 1995;24:64-67.

3.Kieffer J, Winkler G, Van Hove L, Walsh A., Thomann P., Wyss S., Eggenberger E. and Lutz H. Evaluation of the Cell-Dyn 3500 haematology instrument for the analysis of the mouse and rat blood. Comparative Clinical Pathology. 1999;9:92-106.

4.Hennesy M, Buckley T.C., Leadon D.P, Scott C.S. Automated analysis of blood samples from thoroughbred horses with the Abbot cell DYN 3500 (CD3500). Comparative Clinical Pathology. 1998;8:150-158.

5.Lilliehook I, Larsson B. Evaluation of Cell-Dyn 3500, a haematological instrument adapted for testing animal samples. Svensk-Veterinartidning. 1998;50:643-648.

6.Bleul U., Sobiraj A., Bostedt H. Evaluation of the CellDyn 3500 Haematology Analyser for Bovine Blood. Comparative Clinical Pathology. 2002;11:201-210.

7.Lilliehook I, Wall H, Tauson R, Tvedten H. Differential leukocyte counts determined in chicken blood using the Cell-Dyn 3500. Veterinary Clinical Pathology. 2004;33:133-138.

8.Weiser, M G. Hematologic Techniques. Veterinary
Clinics of North America (Small animal Practice). 1981;11:189-208.

9.Low E M, Hill HB, Searcy RL. Simple method for detection of abnormal plasma fibrinogen levels. Technical bulletin of the Registry of Medical Technologists. 1967;37:72-74.

10.Bland J.M, Altman D.G. Statistical methods for assessing agreement between two methods of clinical measurement. Lancet. 1986;8476:307-310.

11.Chow E.Y, Leung K.K. Evaluating the Cell-Dyn 3500 haematology analyzer in an acute general hospital. Clinical and Laboratory Haematology. 1996;18:187-193.

12.Sanzari M, De Toni S, D'osualdo A, Rossetti M., Floriani F., Plebani M. Complete analytical and diagnostic performance of the Abbott Cell Dyn 3500. Panminerva Medicine. 1998;40:116-125.

13.Buttarello M., Gadotti M., Lorenz C., Toffalori E., Ceschini N., Valentini A, Rizzotti P. Evaluation of four automated hematology analysers. American Journal of Clinical Pathology. 1992; 97:345-352.

14.Al-Ismail SA, Bond K, Carter AB, Grant D., Machin SJ., Patterson K.G., Pearman K.J., Pollard Y.C., Popeck, M. X. Two-centre evaluation of the Abbott CELL-DYN 3500 blood counter. Clinical and Laboratory Haematology. 1992;17:11-21.

15.Knoll I.S, Rowell S.L. Clinical Hematology. In: Roskin RE, Meyer DJ. Clinic analysis control, reference values, and system selection. Veterinary Clinics of North American Small Animal Practice. 1996; 26:981-1002.

16.Weiser M.G. Modifications and evaluation of a multichannel blood cell counting system for blood analysis in veterinary hematology. Journal of the American Veterinary Medical Association, 1987; 190:411-423. 